\title{
METHODICAL ASPECTS OF EVALUATING THE EFFECTIVENESS OF NETWORK INTERACTION IN THE FIELD OF TOURIST AND RECREATIONAL SERVICES IN A REGION
}

\author{
Natalia V. Rubtsova \\ Baikal State University, Irkutsk, Russian Federation
}

\begin{abstract}
The issues of assessing the synergistic effects of networking in the area of tourism and recreation services at the regional level are only at the initial stage of discussion. The article presents a critical review of methods for assessing the synergistic effects of the interaction between subjects in socio-economic systems. The author makes the conclusion that the overwhelming majority of the available tools are focused on calculating purely economic (quantitative) synergistic effect and economic efficiency. Besides, the article proves significant limitations in terms of the practical use of methods, including in the area of tourist and recreational services, have been proven. The paper presents the author's methodology for assessing the effectiveness of networking in the area of tourism and recreation services at the regional level. The author also points out characteristics of the components of the cumulative effect of network interaction in the area of tourist and recreational services in the region. The author methodology is for evaluating both synergistic and cumulative effects of network interaction. The paper presents the list of possible indicators. The method was tested on the example of Irkutsk region. The proposed method promotes the development of methodological grounds for studying the effectiveness of networking in the field of tourism and recreation services at the regional level.
\end{abstract}

Key words: network, effect, effectiveness, synergy effect, region, tourism.

Citation. Rubtsova N.V. Methodical Aspects of Evaluating the Effectiveness of Network Interaction in the Field of Tourist and Recreational Services in a Region. Journal of Volgograd State University. Economics, 2020, vol. 22, no. 1, pp. 68-82. (in Russian). DOI: https://doi.org/10.15688/ek.jvolsu.2020.1.7

\section{МЕТОДИЧЕСКИЕ АСПЕКТЫ ОЦЕНКИ ЭФФЕКТИВНОСТИ СЕТЕВОГО ВЗАИМОДЕЙСТВИЯ В СФЕРЕ ТУРИСТСКО-РЕКРЕАЦИОННЫХ УСЛУГ РЕГИОНА}

\section{Наталья Владимировна Рубцова}

Байкальский государственный университет, г. Иркутск, Российская Федерация

\begin{abstract}
Аннотация. К настоящему времени вопросы оценки синергетических эффектов сетевого взаимодействия в сфере туристско-рекреационных услуг на уровне региона находятся лишь в начальной стадии обсуждения. В статье представлен критический обзор методик, посвященных оценке синергетических эффектов взаимодействия субъектов в социально-экономических системах. На основе проведенного анализа сделан вывод, что в подавляющем большинстве имеющийся инструментарий ориентирован на исчисление сугубо экономического (количественного) синергетического эффекта и экономической эффективности. Кроме того, обнаружены существенные ограничения в аспекте его практического использования, в том числе в сфере туристско-рекреационных услуг. В статье представлена авторская методика оценки эффективности сетевого взаимодействия в сфере туристско-рекреационных услуг на уровне региона. Особенностью методики, отличающей ее от подобных разработок, является оценка как синергетических, так и кумулятивного эффектов ․ㅜ сетевого взаимодействия. Автором определен перечень возможных показателей, проведена апробация на (2) примере Иркутской области, которая продемонстрировала ее научную состоятельность и возможность прак-
\end{abstract}


тического использования для проведения соответствующих исследований. Представленная методика призвана способствовать развитию методических и методологических оснований изучения эффективности сетевого взаимодействия в сфере туристско-рекреационных услуг на региональном уровне.

Ключевые слова: сеть, эффект, эффективность, синергетический эффект, регион, туризм.

Цитирование. Рубцова Н. В. Методические аспекты оценки эффективности сетевого взаимодействия в сфере туристско-рекреационных услуг региона // Вестник Волгоградского государственного университета. Экономика. -2020. - Т. 22, № 1. - C. 68-82. - DOI: https://doi.org/10.15688/ek.jvolsu.2020.1.7

\section{Введение}

Изучение влияния межфирменного сотрудничества и кооперации на функционирование и развитие региональной сферы туристско-рекреационных услуг получило активное развитие в первое десятилетие XXI в. в работах ряда зарубежных авторов. В этот период было обосновано, что сотрудничество субъектов сферы туристско-рекреационных услуг региона независимо от формализации возникающих взаимоотношений может обусловить ее успешное развитие, получение монетарных и немонетарных выгод участниками сети взаимоотношений [Copp et al., 2001; Halme, 2001; Keller, 2004; Morrison et al., 2004; Gibson et al., 2005; Dredge, 2006; Erkus, 2008; Lemmetyinen, 2008; Scott et al., 2008; Hilal, 2010]. К настоящему времени существенный интерес и особую актуальность в исследовании сетевого взаимодействия в сфере туристско-рекреационных услуг региона приобрела проблема оценки эффективности межфирменных взаимоотношений. Активный научный поиск направлен на разработку способов оценки возникающих в процессе сетевого взаимодействия синергетических эффектов разного рода. Вместе с тем исследования такого характера объективно сопряжены с возникновением ряда трудностей, поскольку основные выгоды для бизнеса на основе сетевого взаимодействия в сфере туристско-рекреационных услуг имеют преимущественно долгосрочный и нематериальный характер [Gibson, 2005].

\section{Степень разработанности проблемы}

Вопросы оценки синергетических эффектов сетевого взаимодействия в сфере туристско-рекреационных услуг в России к настоящему времени находятся лишь в начальной стадии обсуждения. Изучение имеющейся литературы позволяет констатировать, что исследований, посвященных их изучению примени- тельно к сфере туристско-рекреационных услуг, еще крайне недостаточно. При этом работы, посвященные оценке синергетических эффектов сетевого взаимодействия в туристской сфере регионов России, - и вовсе штучный исследовательский продукт. В таблице 1 представлен обзор разработанных к настоящему времени методик оценивания синергетического эффекта и синергетической эффективности в социально-экономических системах, изучение которых, как представляется, может служить основой для разработки методического инструментария оценки синергетических эффектов сетевого взаимодействия в сфере туристско-рекреационных услуг региона.

Анализ представленных методик позволяет констатировать: в большинстве своем они ориентированы на исчисление сугубо экономического (количественного) синергетического эффекта и экономической эффективности. Также представленные методики имеют существенные ограничения в аспекте их практического использования, что, в частности, затрудняет применение разработанного в их рамках инструментария, в том числе применительно к сфере туристско-рекреационных услуг региона.

Одной из немногочисленных попыток разработки специализированной методики оценки синергетического эффекта межорганизационной сети (кластера) применительно к сфере туристско-рекреационных услуг можно назвать работу А.А. Гармидер. Согласно подходу, представленному данным автором [Гармидер, 2015], синергетический эффект сетевого взаимодействия в туристско-рекреационной сфере оценивается по следующей формуле:

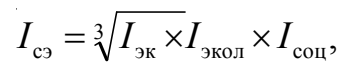

где $I_{\text {сэ }}$ - обобщающий интегральный коэффициент синергетического эффекта; $I_{\text {эк }}, I_{\text {экол }}, I_{\text {соц }}$ - интегральные коэффициенты характеризующие синергетические эффекты в экономической, экологической и социальной сферах региона соответственно. 


\section{Методики оценки синергетического эффекта и эффективности в социально-экономических системах}

\begin{tabular}{|c|c|c|c|c|}
\hline Автор(ы) & $\begin{array}{l}\text { Объект } \\
\text { оценки }\end{array}$ & Формула расчета & Содержание методики & $\begin{array}{c}\text { Ограничения в практиче- } \\
\text { ском использовании }\end{array}$ \\
\hline $\begin{array}{l}\text { Б.Л. Кузнецов, } \\
\text { С.Б. Кузнецова, } \\
\text { Ф.И. Андреева } \\
\text { [Кузнецов и др., } \\
\text { 2005] }\end{array}$ & $\begin{array}{c}\text { Синерге- } \\
\text { тическая } \\
\text { эффек- } \\
\text { тивность }\end{array}$ & $\begin{array}{l}K_{C e 3}=\frac{C_{C e 3}}{3_{C е 3}}=\frac{\Delta[Э \mathrm{P}] * \mathrm{e}^{r}}{\Delta\left[\mathrm{K}^{\lambda}+\mathrm{L}^{\beta}+\mathrm{M}^{\gamma}+\mathrm{I}^{v}+\mathrm{R}^{j} \ldots\right]}, \\
\text { где ССез - экономическая оценка синер- } \\
\text { гетического эффекта; 3Сез - стоимостная } \\
\text { оценка затрат на реализацию синерге- } \\
\text { тического эффекта; } \Delta[Э \mathrm{P}]-\text { изменение } \\
\text { экономического результата вследствие } \\
\text { управляющих воздействий по формиро- } \\
\text { ванию синергетических эффектов }\end{array}$ & $\begin{array}{l}\text { Традиционный спо- } \\
\text { соб расчета экономи- } \\
\text { ческой эффективно- } \\
\text { сти как соотношение } \\
\text { результатов к поне- } \\
\text { сенным на его дос- } \\
\text { тижение затратам }\end{array}$ & $\begin{array}{l}\text { Невозможность соот- } \\
\text { несения числителя со } \\
\text { знаменателем в случае, } \\
\text { если первый представ- } \\
\text { лен нестоимостной ве- } \\
\text { личиной. } \\
\text { Отсутствие обоснова- } \\
\text { ния и способа расчета } \\
\text { показателя } \mathrm{e}^{r}\end{array}$ \\
\hline $\begin{array}{l}\text { Г.Ф. Галиуллина } \\
\text { [Галиуллина, } \\
2008]\end{array}$ & $\begin{array}{c}\text { Синерге- } \\
\text { тическая } \\
\text { эффек- } \\
\text { тивность }\end{array}$ & 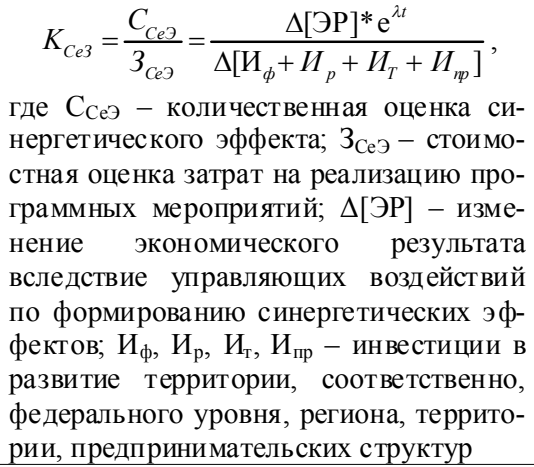 & $\begin{array}{l}\text { Традиционный спо- } \\
\text { соб расчета экономи- } \\
\text { ческой эффективно- } \\
\text { сти как соотношение } \\
\text { результатов к поне- } \\
\text { сенным на его дос- } \\
\text { тижение затратам }\end{array}$ & $\begin{array}{l}\text { Невозможность соот- } \\
\text { несения числителя со } \\
\text { знаменателем в случае, } \\
\text { если первый представ- } \\
\text { лен нестоимостной ве- } \\
\text { личиной. } \\
\text { Отсутствие четких } \\
\text { формулировок и спо- } \\
\text { собов расчета множи- } \\
\text { теля е }{ }^{\lambda t}\end{array}$ \\
\hline $\begin{array}{l}\text { Э.К. Мингалеева } \\
\text { [Мингалеева, } \\
\text { 2009] }\end{array}$ & $\begin{array}{c}\text { Синерге- } \\
\text { тическая } \\
\text { эффек- } \\
\text { тивность }\end{array}$ & 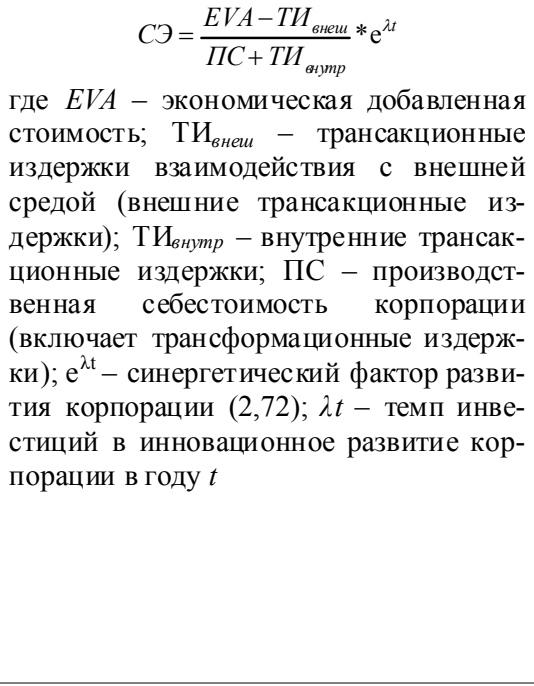 & $\begin{array}{l}\text { Оценка синергетиче- } \\
\text { ской эффективности } \\
\text { в аспекте инноваци- } \\
\text { онного развития, } \\
\text { способ расчета осно- } \\
\text { ван на соотношении } \\
\text { полученных резуль- } \\
\text { татов с затратами }\end{array}$ & $\begin{array}{l}\text { Синергетический эф- } \\
\text { фект связан только с } \\
\text { эффектом от реализа- } \\
\text { ции инноваций. Таким } \\
\text { образом, если инвести- } \\
\text { ции в инновации не } \\
\text { осуществлются, то } \\
\text { синергетический эф- } \\
\text { фект отсутствует как } \\
\text { таковой. } \\
\text { Синергетическая эф- } \\
\text { фективность может } \\
\text { иметь различные зна- } \\
\text { чения относительно } \\
\text { временного периода. } \\
\text { Нарушение логики } \\
\text { формулы расчета эко- } \\
\text { номической эффектив- } \\
\text { ности как соотношение } \\
\text { результата с затратами }\end{array}$ \\
\hline $\begin{array}{l}\text { Л.А. Мусаев } \\
{[\text { Мусаев, 2011] }}\end{array}$ & $\begin{array}{l}\text { Синерге- } \\
\text { тический } \\
\text { эффект } \\
\text { региона }\end{array}$ & $\begin{array}{l}Э_{\text {с.региона }}=\sum_{h=1}^{r} Э_{\text {с.интегр. }}+\sum_{j=1}^{m} Э_{\text {с.неинтегр }} \\
Э_{\text {c.интегр. }}-\text { синергетический эффект } \mathrm{h} \text { ин- } \\
\text { тегрирующих субъектов; } h-\text { количество } \\
\text { субъектов, вх одящих в сеть, } h=1 \ldots r ; \\
Э_{\text {c.неинтегр. }} \text { - синергетический эффект } \mathrm{j} \\
\text { не интегрирующих субъектов, располо- } \\
\text { женных на данной территории (субъек- } \\
\text { ты не входящие в сетевые объедине- } \\
\text { ния); } j-\text { количество субъектов, не вхо- } \\
\text { дящих в сеть, } j=1 . . m\end{array}$ & $\begin{array}{l}\text { Оценка синергетиче- } \\
\text { ского эффекта пред- } \\
\text { полагает учет эффек- } \\
\text { тов взаимодействия } \\
\text { бизнес-структур, a } \\
\text { также других субъек- } \\
\text { тов социально- } \\
\text { экономической сис- } \\
\text { темы }\end{array}$ & $\begin{array}{l}\text { Отсутствие обоснова- } \\
\text { ния и способов расчета } \\
\text { величины синергети- } \\
\text { ческих эффектов }\end{array}$ \\
\hline
\end{tabular}


Н.В. Рубиова. Методические аспекты оценки эффективности сетевого взаимодействия

Окончание таблицы 1

\begin{tabular}{|c|c|c|c|c|}
\hline Автор(ы) & $\begin{array}{l}\text { Объект } \\
\text { оценки }\end{array}$ & Формула расчета & Содержание методики & $\begin{array}{l}\text { Ограничения в практиче- } \\
\text { ском использовании }\end{array}$ \\
\hline $\begin{array}{l}\text { T.А Никулина, } \\
\text { И.М. Романова, } \\
\text { Ю.Д. Шмидт } \\
\text { [Никулина и др., } \\
\text { 2015] }\end{array}$ & $\begin{array}{c}\text { Синерге- } \\
\text { тический } \\
\text { эффект } \\
\text { функцио- } \\
\text { нирова- } \\
\text { ния кор- } \\
\text { поратив- } \\
\text { ных роз- } \\
\text { ничных } \\
\text { торговых } \\
\text { сетей }\end{array}$ & $\begin{array}{l}\text { СЭрc=Эрc- } \sum_{1}^{n} Э i \\
\text { СЭрс - общий синергетический эффект } \\
\text { функционирования корпоративной роз- } \\
\text { ничной торговой сети (РС); Эрc - эф- } \\
\text { фект от совместного функционирования } \\
\text { торговых предприятий в составе корпо- } \\
\text { ративной розничной торговой сети; Э1, } \\
\text { Э2..., Эn - эффекты функционирования } \\
\text { розничных торговых предприятий, вхо- } \\
\text { дящих в розничную сеть, при условии } \\
\text { их функционирования вне корпоратив- } \\
\text { ной розничной торговой сети, } I=1, \ldots, n\end{array}$ & $\begin{array}{l}\text { Расчет синергетиче- } \\
\text { ского эффекта состо- } \\
\text { ит в расчете разницы } \\
\text { между выбранными } \\
\text { показателями дея- } \\
\text { тельности сети в це- } \\
\text { лом и суммой значе- } \\
\text { ний показателей дея- } \\
\text { тельности отдельных } \\
\text { торговых предпри- } \\
\text { ятий сети при усло- } \\
\text { вии их функциониро- } \\
\text { вания самостоятель- } \\
\text { но вне корпоратив- } \\
\text { ной розничной сети }\end{array}$ & $\begin{array}{l}\text { Методика основана на } \\
\text { доходном подходе. Та- } \\
\text { ким образом, оценке } \\
\text { подвергается лишь мо- } \\
\text { нетарная (экономиче- } \\
\text { ская) составляющая } \\
\text { синергетического эф- } \\
\text { фекта }\end{array}$ \\
\hline $\begin{array}{l}\text { Т.А. Левченко, } \\
\text { Е.В. Тунгусова } \\
\text { [Левченко и др., } \\
2017 \text { ] }\end{array}$ & $\begin{array}{c}\text { Синерге- } \\
\text { тический } \\
\text { эффект } \\
\text { кластера }\end{array}$ & 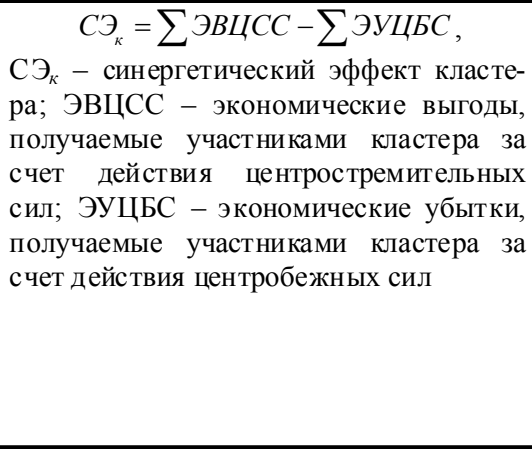 & $\begin{array}{l}\text { Оценка абсолютной } \\
\text { величины синергети- } \\
\text { ческого эффекта как } \\
\text { разности между по- } \\
\text { лученными результа- } \\
\text { тами и затратами с } \\
\text { учетом воздействия } \\
\text { центростремитель- } \\
\text { ных и центробежных } \\
\text { сил }\end{array}$ & $\begin{array}{l}\text { Позволяет осуществ- } \\
\text { лять оценку только } \\
\text { экономического синер- } \\
\text { гетического эффекта. } \\
\text { Отсутствие четких } \\
\text { формулировок при оп- } \\
\text { ределении центрост- } \\
\text { ремительных и цен- } \\
\text { тробежных сил обу- } \\
\text { словливает существен- } \\
\text { ные трудности в полу- } \\
\text { чении исходных дан- } \\
\text { ных для расчета }\end{array}$ \\
\hline
\end{tabular}

Примечание. Составлено автором.

Интегральные коэффициенты синергетических экономического, экологического и социального эффектов вычисляются аналогичным способом - при помощи извлечения кубического корня из трех показателей. При этом исходными данными для расчета экономического синергетического эффекта выступают Эд.П., Эн.П., Эи.чк. - эффекты прироста денежных потоков, налоговых платежей, инвестирования в человеческий капитал соответственно; экологического - Эс.в., Эс.п.о., Эс.з.р. - эффекты снижения водопотребления, производства отходов и сохранения земельных ресурсов соответственно; социального - Эк.о., Эр.с.п., Эм.с.т. - эффекты повышения качества оздоровления, реализации социальных программ, материального стимулирования труда сотрудников соответственно [Гармидер, 2015].

Достоинством названного подхода можно назвать ориентированность на разноаспектную оценку синергетического эффекта сетевого взаимодействия в сфере туристско-рекреационных услуг региона. Вместе с тем эта методика, по нашему мнению, также обладает рядом существенных недостатков.
Во-первых, представленная формула расчета предполагает оценку не синергетического эффекта как такового, а коэффициента, его характеризующего. Идентификация полученного результата, по мнению автора методики, осуществляется с помощью классификационной шкалы оценки интервалов, рассчитанной по функции Стерджеса-Лукса: низкий (от 0,000 до 0,100 ), приемлемый (от 0,101 до $0,200)$, средний (от 0,201 до 0,300 ), высокий $(>0,301)$. Вместе с тем субъективным и необоснованным, на наш взгляд, является выбор для расчета интегральных коэффициентов корня третьей степени (полагаем, что основанием этому служит наличие произведения трех составляющих в представленной формуле расчета). Это замечание справедливо и в отношении расчета интегральных коэффициентов экономического, экологического и социального синергетических эффектов. Напомним, что извлечение кубического корня возможно и из отрицательных чисел, соответственно полученное значение коэффициента может быть и отрицательным. При этом представленная автором классификационная шкала априори 
предполагает получение коэффициента синергетического эффекта выше нуля, то есть только нулевой или положительный синергетический эффект.

Во-вторых, в формулах расчета интегральных коэффициентов (составляющих обобщающего коэффициента синергетического эффекта сетевого взаимодействия) остались без внимания специфические характеристики, имеющие отношение к сфере туристско-рекреационных услуг, что ставит под сомнение целесообразность применения предложенного подхода для оценки синергетического эффекта применительно к данной сфере деятельности.

В-третьих, не совсем понятно и необоснованно, на наш взгляд, включение в формулу расчета экономического синергетического эффекта показателя «инвестирование в человеческий капитал» и в формулу расчета социального синергетического эффекта - показателя «материальное стимулирование труда сотрудников». Данные показатели, как представляется, имеют весьма отдаленное отношение к сетевому взаимодействию субъектов сферы туристско-рекреационных услуг, при этом не характеризуют соответственно его экономическую и социальную стороны.

B-четвертых, отсутствует обоснование включения используемых показателей в формулы расчета интегральных коэффициентов, характеризующих синергетические эффекты в экономической, экологической и социальной сфере региона. Также при расчете интегрального коэффициента социального синергетического эффекта не используются такие качественные показатели, характеризующие эффекты сетевого взаимодействия, как повышение конкурентоспособности участников сети, ориентация на долгосрочное сотрудничество, уровень удовлетворенности взаимоотношениями, уровень доверия между партнерами, повышение качества туристского продукта и т. д.

B-пятых, нет конкретики в способах расчета показателей, входящих в формулы расчета интегральных коэффициентов, характеризующих синергетические эффекты в экономической, экологической и социальной сфере региона. Например, как определить эффект инвестирования в человеческий капитал, какова формула его расчета, в каких единицах он измеряется? Аналогичное замечание справедливо и в отношении показателей «эффекты снижения водопотребления, производства отходов и сохранения земельных ресурсов», «эффекты повышения качества оздоровления, реализации социальных программ, материального стимулирования труда сотрудников». Автором не представлены практические расчетные модели упомянутых показателей, а также единицы их измерения.

Таким образом, в представленной методике просматривается субъективный, неаргументированный и неточный подход к обоснованию и расчету синергетического эффекта сетевого взаимодействия в сфере туристскорекреационных услуг региона, что ставит под сомнение целесообразность и практическую значимость ее использования.

Также следует особо подчеркнуть, что в настоящее время не до конца решенным остается вопрос о перечне возможных показателей для оценки немонетарного синергетического эффекта в сфере туристско-рекреационных услуг региона. В качестве показателей, которые могут быть использованы для подобной оценки, специалисты рекомендуют: снижение трансакционных издержек, улучшение инвестиционного климата, улучшение качества туристского продукта, снижение сроков разработки и внедрения инноваций, преодоление «ресурсных разрывов» и создание конкурентных преимуществ, сокращение сроков выхода на новые рынки, снижение рисков и рост управляемости взаимоотношений, ориентация на долгосрочное сотрудничество, уровень удовлетворенности взаимоотношениями, уровень доверия между партнерами, степень выполнения взаимных обязательств, приверженность / лояльность фирм, персональность взаимоотношений, справедливость взаимоотношений, уровень кооперации / взаимодействия и др. Достаточно обширный перечень возможных показателей, характеризующих качественный аспект сетевого взаимодействия в сфере туристско-рекреационных услуг, отражает стремление наиболее точно передать многогранность и раскрыть потенциал данного явления. Однако настолько широкий спектр параметров создает дополнительные трудности для анализа и измерения немонетарного синергетического эффекта сете- 
вого взаимодействия в сфере туристско-рекреационных услуг. Представляется, что указанный перечень параметров не является окончательным, требует дальнейшей проработки с обоснованием соответствующих методик измерения. Кроме того, значительное число перечисленных выше показателей может быть оценено лишь посредством экспертных оценок, что обусловливает необходимость разработки и обоснования возможных шкал измерения для проведения подобных исследований. Важно подчеркнуть, что выбор показателей и соответствующих методик их оценивания во многом обусловлен имеющейся в распоряжении исследователя статистической и информационной базой, доступностью необходимых источников информации.

Таким образом, проведенный анализ методического инструментария, разработанного для оценки синергетического эффекта и эффективности в социально-экономических системах, позволяет констатировать недостаточную проработанность методики оценки синергетического эффекта и эффективности применительно к сфере туристско-рекреационных услуг региона, что предопределяет необходимость ее дальнейшей разработки.

Прежде всего, обратимся к обоснованию показателей, которые будут оцениваться. Важными условиями их отбора, по нашему мнению, являются возможность их практического использования и наличие источников необходимых данных. В связи с этим хотелось бы рассмотреть перечень показателей эффективности межфирменного взаимодействия, предложенный в работе А.С. Бессоновой. Отмечая важность изучения эффективности сетевого взаимодействия в сфере туристско-рекреационных услуг, исследователь предлагает использовать следующую группу индикаторов для оценки синергетических эффектов: рост качества производственных мощностей, ресурсов и базы информационных технологий; повышение конкурентоспособности межорганизационной сети; расширение роли межорганизационной сети; укрепление сетей сотрудничества [Бессонова, 2012].

В таблице 2 представлен критический обзор индикаторов и соответствующих им субиндикаторов, предложенных данным автором, который был осуществлен нами с позиции трех критериев: характер индикатора, возможность практического использования и источник исходных данных. Представленный критический обзор позволяет констатировать, с одной стороны, недостаточную проработанность рассматриваемого перечня индикаторов (отсутствует обоснование формирования перечня субиндикаторов по каждому индикатору, имеет место дублирование субиндикаторов в разных индикаторах), с другой - наличие ряда проблем при их практическом использовании.

К числу наиболее существенных ограничений, по нашему мнению, относятся:

1. Сочетание во всех индикаторах количественных и качественных субиндикаторов, что обусловливает существенные трудности при расчете их величины, практической оценке синергетических эффектов сетевого взаимодействия в сфере туристско-рекреационных услуг.

2. Необоснованное дублирование субиндикаторов в разных индикаторах, в частности, субиндикатор «повышение качества услуг» присутствует как в индикаторе «рост качества производственных мощностей, ресурсов и базы информационных технологий», так и в индикаторе «повышение конкурентоспособности межорганизационной сети»; субиндикатор «подготовка и реализация совместных кооперационных проектов в области подготовки и переподготовки человеческих ресурсов» присутствует как в индикаторе «рост качества производственных мощностей, ресурсов и базы информационных технологий», так и в индикаторе «укрепление сетей сотрудничества» в рамках субиндикатора «число совместных мероприятий, количество участников», что может привести к искажению общей оценки синергетических эффектов.

3. Необходимость использования широкого круга информационных источников (официальных и неофициальных) и дополнительный поиск специфической информации при отсутствующих рекомендациях по ее сбору.

4. Существенные трудности в практической оценке ряда количественных и качественных индикаторов, в частности, «снижение совокупных затрат на формирование туристического продукта»; «расширение числа контактов и уровень сотрудничества с другими сетями». 


\section{Критический обзор индикаторов и субиндикаторов эффективности} межфирменного взаимодействия А.С. Бессоновой

\begin{tabular}{|c|c|c|c|c|}
\hline Индикатор & Субиндикатор & $\begin{array}{c}\text { Характер } \\
\text { индикатора }\end{array}$ & $\begin{array}{c}\text { Возможность практической оценки } \\
\text { индикатора }\end{array}$ & $\begin{array}{c}\text { Источник исходных } \\
\text { данных } \\
\end{array}$ \\
\hline \multirow[t]{6}{*}{$\begin{array}{l}\text { Рост качества про- } \\
\text { изводственных } \\
\text { мощностей, ресур- } \\
\text { сов и базы инфор- } \\
\text { мационных техно- } \\
\text { логий }\end{array}$} & $\begin{array}{l}\text { Снижение совокупных } \\
\text { затрат на формирова- } \\
\text { ние туристического } \\
\text { продукта }\end{array}$ & $\begin{array}{l}\text { Количест- } \\
\text { венный }\end{array}$ & $\begin{array}{l}\text { Практическая оценка вызывает } \\
\text { существенные трудности, по- } \\
\text { скольку снижение затрат может } \\
\text { быть вызвано другими фактора- } \\
\text { ми (например, изменением курса } \\
\text { валют, государственным регули- } \\
\text { рованием цен) }\end{array}$ & $\begin{array}{l}\text { Документы внутрен- } \\
\text { ней отчетности субъ- } \\
\text { ектов межорганизаци- } \\
\text { онной сети }\end{array}$ \\
\hline & $\begin{array}{l}\text { Повышение качества } \\
\text { услуг за счет эффекта } \\
\text { синергии }\end{array}$ & $\begin{array}{l}\text { Качествен- } \\
\text { ный }\end{array}$ & $\begin{array}{l}\text { Практическая оценка возможна, } \\
\text { имеет ярко выраженный субъек- } \\
\text { тивный характер }\end{array}$ & $\begin{array}{l}\text { Результаты опросов } \\
\text { потребителей турист- } \\
\text { ско-рекреационных } \\
\text { услуг }\end{array}$ \\
\hline & $\begin{array}{l}\text { Упрощенные логисти- } \\
\text { ческие связи между } \\
\text { участниками за счет } \\
\text { внедрения информаци- } \\
\text { онных технологий }\end{array}$ & $\begin{array}{l}\text { Качествен- } \\
\text { ный }\end{array}$ & $\begin{array}{l}\text { Могут быть сложности при не- } \\
\text { однозначных оценках экспертов }\end{array}$ & Экспертная оценка \\
\hline & $\begin{array}{l}\text { Количество вовлечен- } \\
\text { ных в сеть участников }\end{array}$ & $\begin{array}{l}\text { Количест- } \\
\text { венный }\end{array}$ & $\begin{array}{l}\text { Практическая оценка возможна, } \\
\text { но вызывает некоторые затруд- } \\
\text { нения }\end{array}$ & $\begin{array}{l}\text { Статистическая от- } \\
\text { четность, результаты } \\
\text { специальных исследо- } \\
\text { ваний }\end{array}$ \\
\hline & $\begin{array}{l}\text { Создание новых рабо- } \\
\text { чих мест }\end{array}$ & $\begin{array}{l}\text { Количест- } \\
\text { венный }\end{array}$ & $\begin{array}{l}\text { Практическая оценка возможна и } \\
\text { не вызывает затруднений }\end{array}$ & $\begin{array}{l}\text { Статистическая от- } \\
\text { четность }\end{array}$ \\
\hline & $\begin{array}{l}\text { Подготовка и реализа- } \\
\text { ция совместных коопе- } \\
\text { рационных проектов в } \\
\text { области подготовки и } \\
\text { переподготовки чело- } \\
\text { веческих ресурсов }\end{array}$ & $\begin{array}{l}\text { Количест- } \\
\text { венный }\end{array}$ & $\begin{array}{l}\text { Практическая оценка возможна и } \\
\text { не вызывает затруднений }\end{array}$ & Экспертный опрос \\
\hline \multirow{3}{*}{$\begin{array}{l}\text { Повышение конку- } \\
\text { рентоспособности } \\
\text { межорганизацион- } \\
\text { ной сети }\end{array}$} & $\begin{array}{l}\text { Уровень производи- } \\
\text { тельности труда }\end{array}$ & $\begin{array}{l}\text { Количест- } \\
\text { венный }\end{array}$ & $\begin{array}{l}\text { Практическая оценка возможна и } \\
\text { не вызывает затруднений }\end{array}$ & $\begin{array}{l}\text { Статистическая от- } \\
\text { четность }\end{array}$ \\
\hline & $\begin{array}{l}\text { Улучшение основных } \\
\text { показателей производ- } \\
\text { ственно-хозяйственной } \\
\text { деятельности }\end{array}$ & $\begin{array}{l}\text { Количест- } \\
\text { венный }\end{array}$ & $\begin{array}{l}\text { Не определен круг основных по- } \\
\text { казателей производственно- } \\
\text { хозяйственной деятельности, од- } \\
\text { нако при ликвидации указанного } \\
\text { пробела оценка индикатора воз- } \\
\text { можна }\end{array}$ & $\begin{array}{l}\text { Документы внутрен- } \\
\text { ней отчетности субъ- } \\
\text { ектов межорганизаци- } \\
\text { онной сети }\end{array}$ \\
\hline & $\begin{array}{l}\text { Повышение качества } \\
\text { предоставляемых тури- } \\
\text { стических услуг }\end{array}$ & $\begin{array}{l}\text { Качествен- } \\
\text { ный }\end{array}$ & $\begin{array}{l}\text { Совпадает с субиндикатором в } \\
\text { индикаторе «рост качества про- } \\
\text { изводственных мощностей, ре- } \\
\text { сурсов и базы информационных } \\
\text { технологий» }\end{array}$ & $\begin{array}{l}\text { Результаты опросов } \\
\text { потребителей турист- } \\
\text { ско-рекреационных } \\
\text { услуг }\end{array}$ \\
\hline \multirow[t]{4}{*}{$\begin{array}{l}\text { Расширение роли } \\
\text { межорганизацион- } \\
\text { ной сети }\end{array}$} & $\begin{array}{l}\text { Создание единого } \\
\text { имиджа сети и ее уча- } \\
\text { стников }\end{array}$ & $\begin{array}{l}\text { Качествен- } \\
\text { ный }\end{array}$ & $\begin{array}{l}\text { Могут быть сложности при не- } \\
\text { однозначных оценках экспертов }\end{array}$ & Экспертная оценка \\
\hline & $\begin{array}{l}\text { Повышение осведом- } \\
\text { ленности о потребно- } \\
\text { стях, имеющихся у по- } \\
\text { тенциальных туристов } \\
\text { на национальном и ре- } \\
\text { гиональном рынках } \\
\end{array}$ & $\begin{array}{l}\text { Качествен- } \\
\text { ный }\end{array}$ & $\begin{array}{l}\text { Могут быть сложности при не- } \\
\text { однозначных оценках }\end{array}$ & Экспертная оценка \\
\hline & $\begin{array}{l}\text { Количество привлечен- } \\
\text { ных инвестиций }\end{array}$ & $\begin{array}{l}\text { Количест- } \\
\text { венный }\end{array}$ & $\begin{array}{l}\text { Практическая оценка возможна и } \\
\text { не вызывает затруднений }\end{array}$ & $\begin{array}{l}\text { Статистическая от- } \\
\text { четность }\end{array}$ \\
\hline & $\begin{array}{l}\text { Число совместных } \\
\text { предприятий }\end{array}$ & $\begin{array}{l}\text { Количест- } \\
\text { венный }\end{array}$ & $\begin{array}{l}\text { Практическая оценка возможна и } \\
\text { не вызывает затруднений }\end{array}$ & $\begin{array}{l}\text { Статистическая от- } \\
\text { четность }\end{array}$ \\
\hline
\end{tabular}


Н.В. Рубцова. Методические аспекты оценки эффективности сетевого взаимодействия

\begin{tabular}{|c|c|c|c|c|}
\hline \multicolumn{5}{|c|}{ Окончание таолицьы } \\
\hline Индикатор & Субиндикатор & $\begin{array}{c}\text { Характер } \\
\text { индикатора }\end{array}$ & $\begin{array}{c}\text { Возможность практической оценки } \\
\text { индикатора }\end{array}$ & $\begin{array}{c}\text { Источник исходных } \\
\text { данных } \\
\end{array}$ \\
\hline \multirow[t]{3}{*}{$\begin{array}{l}\text { Укрепление сетей } \\
\text { сотрудничества }\end{array}$} & $\begin{array}{l}\text { Расширение числа кон- } \\
\text { тактов и уровень со- } \\
\text { трудничества с други- } \\
\text { ми сетями }\end{array}$ & $\begin{array}{l}\text { Качествен- } \\
\text { ный }\end{array}$ & $\begin{array}{l}\text { Заключает в себе два разных ин- } \\
\text { дикатора, могут быть сложности } \\
\text { при неоднозначных оценках экс- } \\
\text { пертов }\end{array}$ & Экспертная оценка \\
\hline & $\begin{array}{l}\text { Количество новых } \\
\text { партнеров }\end{array}$ & $\begin{array}{l}\text { Количест- } \\
\text { венный }\end{array}$ & $\begin{array}{l}\text { Практическая оценка возможна и } \\
\text { не вызывает затруднений }\end{array}$ & $\begin{array}{l}\text { Статистическая от- } \\
\text { четность }\end{array}$ \\
\hline & $\begin{array}{l}\text { Число совместных ме- } \\
\text { роприятий, количество } \\
\text { участников }\end{array}$ & $\begin{array}{l}\text { Количест- } \\
\text { венный }\end{array}$ & $\begin{array}{l}\text { Заключает в себе два разных ин- } \\
\text { дикатора, совпадает с субинди- } \\
\text { катором в индикаторе «рост ка- } \\
\text { чества производственных мощ- } \\
\text { ностей, ресурсов и базы инфор- } \\
\text { мационных технологий» }\end{array}$ & $\begin{array}{l}\text { Статистическая от- } \\
\text { четность }\end{array}$ \\
\hline
\end{tabular}

Примечание. Составлено автором.

5. Объективные трудности в получении необходимой информации, источниками которой служит внутренняя документация субъектов сетевого взаимодействия, в частности, сказанное справедливо в отношении индикаторов «снижение совокупных затрат на формирование туристического продукта»; «улучшение основных показателей производственно-хозяйственной деятельности».

Отметим, что отсутствие в указанной работе [Бессонова, 2012] методики расчета синергетических эффектов по предложенному набору индикаторов также существенно ограничивает возможность их практического использования.

Таким образом, недостаточная разработанность вопросов практической оценки синергетических эффектов, возникающих в результате сетевого взаимодействия в сфере туристско-рекреационных услуг региона, объективно обусловливает необходимость разработки соответствующих методических оснований. Как представляется, их формирование целесообразно осуществлять в ракурсе оценки как количественного, так и качественного аспектов синергетического эффекта сетевого взаимодействия в сфере туристско-рекреационных услуг региона.

\section{Эффекты сетевого взаимодействия в сфере туристско-рекреационных услуг региона}

По мнению ряда исследователей, включая автора данной статьи, межфирменное взаимодействие в сфере туристско-рекреационных услуг региона происходит по обоюдному согласию всех участников сети, что собственно и формирует туристский продукт как таковой. В связи с этим синергетический эффект сетевого взаимодействия всегда положителен, в противном случае (независимо от формализации условий взаимодействия) никакого туристского продукта бы не формировалось, в этом состоит специфика сетевого взаимодействия в сфере туристско-рекреационных услуг региона. Вместе с тем в разные временные периоды синергетический эффект может быть большим либо меньшим. Сравнение величин получаемых синергетических эффектов собственно и определяет эффективность сетевого взаимодействия в сфере туристско-рекреационных услуг региона.

Общие экономические выгоды от сетевого взаимодействия в сфере туристско-рекреационных услуг региона, как представляется, складываются из следующих источников: выгода от совместной хозяйственной и маркетинговой деятельности, выгода от совместной инвестиционной деятельности, выгода от расширения рынков сбыта. Помимо этого взаимодействие в сфере туристско-рекреационных услуг обусловливает и формирование немонетарных выгод, таких как ориентация на долгосрочное сотрудничество, уровень удовлетворенности взаимоотношениями, уровень доверия между партнерами, степень выполнения взаимных обязательств, приверженность / лояльность фирм, персональность взаимоотношений, справедливость взаимоотношений, уровень кооперации / взаимодействия и др.

Предлагаемый нами методический инструментарий базируется на определении кумулятивного эффекта сетевого взаимодей- 
ствия в сфере туристско-рекреационных услуг региона ${ }^{1}$. Под кумулятивным эффектом сетевого взаимодействия в сфере туристскорекреационных услуг региона мы понимаем количественные и качественные результаты (синергетические эффекты) длительного взаимодействия субъектов туристско-рекреационной сферы на уровне региона.

Кумулятивный эффект в сфере туристско-рекреационных услуг региона - это результат, проявляющийся в процессе длительного и эффективного взаимодействия субъектов сферы туристско-рекреационных услуг региона в аспекте достижения общих стратегических целей, который может быть представлен в виде совокупности количественных и качественных синергетических эффектов.

Характеристика количественной и качественной составляющих кумулятивного эффекта сетевого взаимодействия в сфере туристско-рекреационных услуг региона представлена в таблице 3.
При этом очевидна взаимосвязь между количественным и качественным аспектами кумулятивного эффекта. Например, долгосрочное эффективное сотрудничество партнеров туристской сферы, направленное на продвижение туристского продукта, повышение качества обслуживания, обусловит популярность туристского направления, что приведет к увеличению туристского потока, следовательно, увеличатся объем продаж, выручка и прибыль. Напротив, отсутствие общих целей по продвижению туристского направления, развития туристской инфраструктуры, игнорирование проблем загрязнения окружающей среды в долгосрочной перспективе приведут ко снижению популярности туристской дестинации (территории) и уменьшению количественной (экономической) составляющей кумулятивного эффекта.

Как видим, количественный и качественный аспекты кумулятивного эффекта характеризуют разные (хоть и взаимообусловлен-

Таблииа 3

\section{Характеристика составляющих кумулятивного эффекта сетевого взаимодействия} в сфере туристско-рекреационных услуг региона

\begin{tabular}{|c|c|c|}
\hline Характеристика & $\begin{array}{l}\text { Количественный (монетарный) } \\
\text { синергетический эффект }\end{array}$ & $\begin{array}{l}\text { Качественный (немонетарный) } \\
\text { синергетический эффект }\end{array}$ \\
\hline Содержание & $\begin{array}{l}\text { Результат совместной деятельности } \\
\text { субъектов сферы туристско-рекреа- } \\
\text { ционных услуг как сети создания цен- } \\
\text { ности туристского продукта }\end{array}$ & $\begin{array}{l}\text { Результат длительного взаимодействия субъ- } \\
\text { ектов сферы туристско-рекреационных услуг } \\
\text { в аспекте достижения общих стратегических } \\
\text { целей }\end{array}$ \\
\hline $\begin{array}{l}\text { Основные взаимодей- } \\
\text { ствующие субъекты }\end{array}$ & Субъекты туристской индустрии & $\begin{array}{l}\text { Субъекты сферы туристско-рекреационных } \\
\text { услуг, контактные аудитории }\end{array}$ \\
\hline Характер управления & Оперативный & Стратегический \\
\hline $\begin{array}{l}\text { Временной период } \\
\text { оценки }\end{array}$ & Краткосрочный & Долгосрочный \\
\hline Показатели оценки & Количественные & Качественные \\
\hline Возможные показатели & $\begin{array}{l}\text { Размер трансакционных издержек. } \\
\text { Уровень загруженности производст- } \\
\text { венных мощностей. } \\
\text { Объем и качество инвестиций. } \\
\text { Расходы на совершенствование и разра- } \\
\text { ботку новых продуктов и технологий. } \\
\text { Количество участников сети }\end{array}$ & $\begin{array}{l}\text { Совместимость целей компаний (индивиду- } \\
\text { альных и коллективных) и степень их реали- } \\
\text { зации. } \\
\text { Качество туристского продукта. } \\
\text { Сроки разработки и внедрения инноваций. } \\
\text { Конкурентные преимущества. } \\
\text { Сроки выхода на новые рынки. } \\
\text { Снижение рисков. } \\
\text { Управляемость взаимоотношений. } \\
\text { Долгосрочное сотрудничесто. } \\
\text { Уровень удовлетворенности взаимоотноше- } \\
\text { ниями. } \\
\text { Уровень доверия между партнерами. } \\
\text { Степень выполнения взаимных обязательств. } \\
\text { Персональность взаимоотношений. } \\
\text { Справедливость взаимоотношений. } \\
\text { Уровень кооперации / взаимодействия }\end{array}$ \\
\hline
\end{tabular}

Примечание. Составлено автором. 
H.В. Рубцова. Методические аспекты оценки эффективности сетевого взаимодействия

ные) стороны сетевого взаимодействия субъектов сферы туристско-рекреационных услуг (соответственно, монетарный и немонетарный), требуют использования собственных методик и показателей для оценки.

\section{Методика оценки эффективности сетевого взаимодействия в сфере туристско-рекреационных услуг региона}

На основании изложенного показатель эффективности сетевого взаимодействия в сфере туристско-рекреационных услуг региона предлагается рассчитывать по следующей формуле:

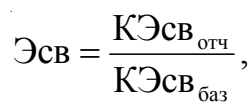

где Эсв - показатель эффективности сетевого взаимодействия в сфере туристско-рекреационных услуг региона; КЭсв отч - кумулятивный эффект сетевого взаимодействия в отчетный период; КЭсв ${ }_{\text {баз }}-$ кумулятивный эффект сетевого взаимодействия в базисный период.

Сопоставление величин кумулятивного эффекта в базисном и отчетном периоде позволяет сделать вывод об уровне достигнутой интеграции, целесообразности и долговременности сетевого объединения, эффективности сетевого взаимодействия в сфере туристско-рекреационных услуг региона в социоэкономическом аспекте.

Показатель кумулятивного эффекта сетевого взаимодействия в базисном и отчетном периоде рассчитывается по следующей формуле:

$$
\text { КЭсв }=\sqrt{Э Э с в \times С Э с в, ~}
$$

где КЭсв - кумулятивный эффект сетевого взаимодействия в сфере туристско-рекреационных услуг региона; ЭЭсв - экономический синергетический эффект сетевого взаимодействия в сфере туристско-рекреационных услуг региона; СЭсв - социальный синергетический эффект сетевого взаимодействия в сфере туристско-рекреационных услуг региона.

Показатель экономического синергетического эффекта сетевого взаимодействия в сфере туристско-рекреационных услуг региона рассчитывается по формуле:

$$
\text { ЭЭсв }=\text { Ки } \times \text { Ктп } \times \text { Ку, }
$$

где ЭЭсв - экономический синергетический эффект сетевого взаимодействия в сфере туристскорекреационных услуг региона; Ки - коэффициент прироста инвестиций в основной капитал организаций сферы туристско-рекреационных услуг региона; Ктп - коэффициент прироста участников сети [предприятий сферы туристско-рекреационных услуг региона (средств размещения и туристских предприятий)]; Ку - коэффициент прироста туристского потока.

Показатель социального синергетического эффекта сетевого взаимодействия в сфере туристско-рекреационных услуг региона рассчитывается по формуле:

$$
\mathrm{CЭ}_{\text {св }}=\frac{\sum_{i=6} a_{i}}{i \times 100},
$$

где СЭсв - социальный синергетический эффект сетевого взаимодействия в сфере туристско-рекреационных услуг региона; $a$ - параметры социального синергетического эффекта сетевого взаимодействия в сфере туристско-рекреационных услуг региона, \%; $i$ - число параметров социального синергетического эффекта сетевого взаимодействия.

По нашему мнению, социальный синергетический эффект сетевого взаимодействия в сфере туристско-рекреационных услуг региона должен определяться на основе специального социологического исследования представителей туристской сферы с обязательным соблюдением требований релевантного формирования выборочной совокупности. Положения, представленные в работах отечественных и зарубежных авторов, позволяют предложить следующий перечень параметров (исходных данных) для расчета показателя, характеризующего социальный синергетический эффект сетевого взаимодействия в сфере туристско-рекреационных услуг региона:

$$
\begin{aligned}
& \text { - справедливость; } \\
& \text { - равноправность; } \\
& \text { - персонифицированность; } \\
& \text { - стабильность; } \\
& \text { - надежность; } \\
& \text { - долгосрочность. }
\end{aligned}
$$


Исходные данные для исчисления показателя социального синергетического эффекта сетевого взаимодействия в сфере туристско-рекреационных услуг региона получаются посредством проведения социологического исследования представителей туристскорекреационной сферы с помощью следующих вопросов: «Как вы оцениваете свои взаимоотношения с вашими бизнес-партнерами? Считаете ли вы сложившиеся взаимоотношения: справедливыми, равноправными, стабильными, надежными, долгосрочными, персонифицированными?».

Расчет показателя социального синергетического эффекта сетевого взаимодействия в сфере туристско-рекреационных услуг региона представляет собой определение доли респондентов (в \%), ответивших на вопрос о характере взаимоотношений утвердительно. Показатель, характеризующий социальный аспект эффективности взаимоотношений, рассчитывается как среднее значение по всем параметрам.

При проведении сравнительного анализа показателя эффективности сетевого взаимодействия в сфере туристско-рекреационных услуг региона, а также показателей, его формирующих, необходимо придерживаться следующих положений:

1. Значение показателя эффективности сетевого взаимодействия в сфере туристскорекреационных услуг региона выше единицы свидетельствует об эффективности сетевого объединения в сфере туристско-рекреационных услуг региона; значения данного показателя меньше единицы свидетельствуют о низкой эффективности сетевого взаимодействия. В случае, если показатель равен единице, делается вывод, что уровень интеграции в сети не изменился.

2. При проведении межрегиональных исследований, сравнительных исследований туристских дестинаций, а также исследований, предполагающих сравнение нескольких временных периодов большей эффективностью сетевого взаимодействия будет характеризоваться та сфера туристско-рекреационных услуг (соответствующего региона, туристской дестинации или временного периода), значения показателей которой будут, с одной стороны, выше единицы, с другой - большими (по сравнению с аналогичными объектами сравнения).

\section{Апробация и выводы}

Апробация предложенной методики оценки проводилась на примере сферы туристско-рекреационных услуг Иркутской области. Важность развития эффективной межфирменной кооперации для устойчивого социально-экономического развития региона отмечается в работах многих авторов [Самаруха, 2012; Санина, 2014; Светник и др., 2011; Чепинога и др., 2017; Чистякова, 2012]. Выбранный нами временной диапазон оценки 20082013-2018 гг. (периодичностью в пять лет) обусловлен спецификой возникновения кумулятивных эффектов в сфере туристско-рекреационных услуг региона, которые формируются и наблюдаются преимущественно в долгосрочной перспективе.

Исходные данные для расчета показателей эффективности сетевого взаимодействия в сфере туристско-рекреационных услуг Иркутской области представлены в таблице 4.

Показатели эффективности сетевого взаимодействия в сфере туристско-рекреационных услуг Иркутской области представлены в таблице 5 .

На основании полученных расчетов показатель эффективности сетевого взаимодействия в сфере туристско-рекреационных услуг Иркутской области равен 2,7 (> 1), что свидетельствует о более высоком уровне достигнутой интеграции, эффективности сетевого объединения в туристской сфере региона в 2018 г. по сравнению с 2013 годом.

\section{Заключение}

Представленная в рамках данной статьи методика призвана способствовать развитию методологических положений изучения эффективности сетевого взаимодействия в сфере туристско-рекреационных услуг на региональном уровне. Проведенная апробация методики на примере Иркутской области продемонстрировала ее научную состоятельность и возможность практического использования для проведения соответствующих исследований. 
Исходные данные для расчета показателей эффективности сетевого взаимодействия в сфере туристско-рекреационных услуг Иркутской области

\begin{tabular}{|c|c|c|c|c|}
\hline \multirow{2}{*}{ Показатель } & \multirow{2}{*}{ Исходные данные } & \multicolumn{3}{|c|}{ Период } \\
\hline & & 2008 & 2013 & 2018 \\
\hline \multirow{3}{*}{$\begin{array}{l}\text { Экономический } \\
\text { синергетический } \\
\text { эффект }\end{array}$} & $\begin{array}{l}\text { Инвестиции в основной капитал организаций сферы } \\
\text { туристско-рекреационных услуг региона, тыс. руб. }\end{array}$ & 8470 & 13421 & 964996 \\
\hline & $\begin{array}{l}\text { Количество участников сети [предприятий сферы } \\
\text { туристско-рекреационных услуг региона (средств } \\
\text { размещения и туристских предприятий)], ед. }\end{array}$ & 350 & 518 & 580 \\
\hline & Величина туристического потока, тыс. чел. & 70,9 & 168,8 & 92,1 \\
\hline \multirow{6}{*}{$\begin{array}{l}\text { Социальный си- } \\
\text { нергетический } \\
\text { эффект }\end{array}$} & Справедливость & - & 61 & 60 \\
\hline & Равноправность & - & 53 & 42 \\
\hline & Персонифицированность & - & 33 & 35 \\
\hline & Стабильность & - & 28 & 30 \\
\hline & Надежность & - & 48 & 42 \\
\hline & Долговечность & - & 20 & 18 \\
\hline
\end{tabular}

Примечание. Источником исходных данных для расчета показателя экономического синергетического эффекта послужили данные Росстат [Единая межведомственная статистическая система, 2018]. Источником информации для расчета социального синергетического эффекта послужили результаты социологических исследований представителей сферы туристско-рекреационных услуг региона, проведенные лично автором в 2013 и 2018 г. (подробнее об исследовании 2013 г. в: [Рубцова, 2014]). В исследовании 2018 г. приняли участие 15 руководителей туристских предприятий (туроператоров и турагентов) и 21 руководитель средств размещения Иркутской области.

Таблица 5

\section{Показатели эффективности сетевого взаимодействия в сфере туристско-рекреационных услуг Иркутской области}

\begin{tabular}{|l|c|r|r|}
\hline \multirow{2}{*}{ Показатель } & \multirow{2}{*}{ Условное } & \multicolumn{2}{|c|}{ Период } \\
\cline { 3 - 4 } & обозначение & 2013 & \multicolumn{1}{c|}{2018} \\
\hline Коэффициент прироста инвестиций в основной капитал & Ки & 1,58 & 71,9 \\
\hline Коэффициент прироста участников сети & Ктп & 1,48 & 1,12 \\
\hline Коэффициент прироста туристского потока & Ку & 2,40 & 0,55 \\
\hline Экономический синергетический эффект & ЭЭсв & 5,610 & 43,940 \\
\hline Социальный синергетический эффект & СЭсв & 0,405 & 0,378 \\
\hline Кумулятивный эффект сетевого взаимодействия & Кэсв & 1,51 & 4,08 \\
\hline Эффективность сетевого взаимодействия & Эсв & \multicolumn{2}{|c}{2,7} \\
\hline
\end{tabular}

Примечание. Составлено автором.

\section{ПРИМЕЧАНИЕ}

${ }^{1}$ Подробнее о возникновении и содержании кумулятивного эффекта в сфере туристско-рекреационных услуг региона в работе: [Рубцова, 2018].

\section{СПИСОК ЛИТЕРАТУРЫ}

Бессонова, А. С. Активизация кооперационного взаимодействия предприятий сферы туризма в формировании кластера горнолыжного туризма и рекреации / А. С. Бессонова // Ученые записки Тавр. нац. ун-та им. В.И. Вернадского. Сер.: Экономика и управление. 2012. - Т. 25 (64), № 4. - С. 17-27.

Галиуллина, Г. Ф. Совершенствование промышленной политики территории с крупным машино- строительным комплексом : автореф. дис. ... канд. экон. наук / Галиуллина Гыльия Фагимовна. - Набережные Челны : ИНЭКА, 2008. - 28 с.

Гармидер, А. А. Подход к оценке синергетического эффекта от кластеризации туристической сферы региона / А. А. Гармидер // Теория и практика общественного развития. - 2015. № 14. - C. 54-56.

Единая межведомственная статистическая система. Электрон. текстовые дан. - Режим доступа: https://fedstat.ru (дата обращения: 01.07.2019).Загл. с экрана.

Кузнецов, Б. Л. Эффективность корпоративного развития / Б. Л. Кузнецов // Экономическая синергетика: Ответы на вызовы и угрозы XXI века : сб. науч. тр. - Набережные Челны : Изд-во Кам. гос. инж.-экон. акад., 2005. C. 119-126. 
Левченко, Т. А. Кластерные структуры: основные характеристики и генерируемый эффект / Т. А. Левченко, Е. В. Тунгусова // Fundamental research. - 2017. - № 3. - C. 144-148.

Мингалеева, Э. К. Институционально-синергетический механизм управления трансакционными издержками вертикально-интегрированной корпорации : автореф. дис. ... канд. экон. наук / Мингалеева Эльмира Камиловна. - Набережные Челны : ИНЭКА, 2009. - 28 c.

Мусаев, Л. А. Оценка синергетического эффекта экономических систем / Л. А. Мусаев // Вестник ЮРГТУ (НПИ). - 2011. - № 3. - С. 132-137.

Никулина, Т. А. Методика оценки синергетического эффекта функционирования корпоративных розничных торговых сетей / Т. А. Никулина, И. М. Романова, Ю. Д. Шмидт // Экономика и предпринимательство. - 2015. - № 3.C. 939-945.

Рубцова, Н. В. Межфирменные отношения в туризме: результаты исследования компаний Прибайкалья / Н. В. Рубцова // Вестник СПбГЭУ. Сер.: Технические науки. - 2014. № $8(75)$. - С. 35-44.

Рубцова, Н. В. Эффекты сетевого взаимодействия в сфере туристско-рекреационных услуг региона (на примере Сибирского федерального округа) / Н. В. Рубцова // Мир экономики и управления. - 2018. - Т. 18, № 4. - С. 217-232. DOI: https://doi.org/10.25205/2542-0429-2018-184-217-232.

Самаруха, В. И. Концепция развития туризма в Байкальском регионе / В. И. Самаруха // Науч.техн. ведомости СПбГПУ. - 2012. - № 3. С. 184-189.

Санина, Л. В. Опыт оказания государственной поддержки субъектам малого и среднего предпринимательства в регионах России / Л. В. Санина // Baikal Research Journal. 2014. - № 3 .

Светник, Т. В. Стратегическое управление созданием особой экономической зоны туристско-рекреационного типа в Республике Бурятия / Т. В. Светник, Т. Ю. Бубаева // Baikal Research Journal. - 2011. - № 5.

Чепинога, О. А. Проблемы функционирования и перспективы развития особых экономических зон в России / О. А. Чепинога, М. В. Солодков, А. Э. Семенова // Baikal Research Journal. - 2017. - T. 8. - № 3. - DOI: https://doi.org/ 10.17150/2411-6262.2017.8(3).4.

Чистякова, О. В. Перспективы развития туристскорекреационной особой экономической зоны «Ворота Байкала» / О.В.Чистякова // Известия Иркут. гос. экон. акад. (Байкал. гос. ун-т экономики и права). - 2012. - № 3. - С. 108-112.
Copp, C. Networking Trends of Small Tourism Businesses in Post-Socialist Slovakia / C. Copp, R. Ivy // Journal of Small Business Management. 2001.-№39 (4). - P. 345-353.

Dredge, D. Policy Networks and the Local Organization of Tourism / D. Dredge// Tourism Management. 2006. - № 27 (2). - P. 269-280.

Erkus, O. H. The Role of Local and Global Networking for Tourism Rms and Clusters: The Case of Antalya / O. H. Erkus // Unpublished PhD Thesis of Middle East Technical University. - Ankara : [s. n.], 2008. $-328 \mathrm{p}$.

Gibson, L. The Local Destination Tourism Network: Development Issues / L. Gibson, P. Lynch, A. Morrison // Tourism and Hospitality Planning \& Development. - 2005. - № 2 (2). - P. 87-99.

Halme, M. Learning for Sustainable Development in Tourism Networks / M. Halme // Business Strategy and the Environment. - 2001. № 10 (2). - P. 100-114.

Hilal, E. O. The Signicance of Networking and Company Size in the Level of Creativeness of Tourism Companies: Antalya Case / E. O. Hilal // European Planning Studies. - 2010. - Vol. 18. № 8. - P. 1247-1266.

Keller, P. The Future of SMEs in Tourism / P. Keller. St. Gallen : AIEST, 2004. - P. 7-21.

Lemmetyinen, A. The Key Capabilities Required for Managing Tourism Business Networks /A. Lemmetyinen, F. Go// Tourism Management. 2008. - №30 (1). - P.31-40.

Morrison, A. International Tourism Network / A. Morrison, P. Lynch, N. Johns // International Journal of Contemporary Hospitality Management. - 2004. № 16(3). - P. 197-202.

Scott, N. Network Analysis and Tourism: From Theory to Practice (Aspects of Tourism) / N. Scott, R. Baggio, C. Cooper. - Clevedon : Channel View Publications, 2008. - 258 p.

\section{REFERENCES}

Bessonova A.S. Aktivizatsiya kooperatsionnogo vzaimodeystviya predpriyatiy sfery turizma $\mathrm{V}$ formirovanii klastera gornolyzhnogo turizma $\mathrm{i}$ rekreatsii [Activation of cooperation of tourism enterprises in the formation of a cluster of ski tourism and recreation]. Uchenye zapiski Tavr. nats. un-ta im. V.I. Vernadskogo. Ser.: Ekonomika i upravlenie, 2012, vol. 25 (64), no. 4, pp. 17-27.

Galiullina G.F. Sovershenstvovanie promyshlennoy politiki territorii s krupnym mashinostroitelnym kompleksom: avtoref. dis. ... kand. ekon. nauk [Improving the Industrial Policy of the Territory 
with a Large Machine-Building Complex. Cand. econ. sci. abs. diss.]. Naberezhnye Chelny, INEKA, 2008. 28 p.

Garmider A.A. Podkhod k otsenke sinergeticheskogo effekta ot klasterizatsii turisticheskoy sfery regiona [Approach to Assessing the Synergistic Effect of Clustering Tourism in the Region]. Teoriya i praktika obshchestvennogo razvitiya [Theory and Practice of Social Development], 2015, no. 14, pp. 54-56.

Edinaya mezhvedomstvennaya statisticheskaya sistema [Integrated Interdepartmental Statistical System]. URL: https://fedstat.ru (accessed 1 July 2019).

Kuznetsov B.L. Effektivnost korporativnogo razvitiya [Corporate Development Efficiency]. Ekonomicheskaya sinergetika: Otvety na vyzovy i ugrozy XXI veka: sb. nauch. tr. [Economic Synergy: Answers to the Challenges and Threats of the $21^{\text {st }}$ Century. Collection of Scientific Works]. Naberezhnye Chelny, Izd-vo Kamskoy gosudarstvennoy inzhenernoekonomicheskoy akademii, 2005, pp. 119-126.

Levchenko T.A., Tungusova E.V. Klasternye struktury: osnovnye kharakteristiki i generiruemyy effekt [Cluster Structures: Main Characteristics and Generated Effect]. Fundamental research, 2017, no. 3, pp. 144-148.

Mingaleeva E.K. Institutsionalno-sinergeticheskiy mekhanizm upravleniya transaktsionnymi izderzhkami vertikalno-integrirovannoy korporatsii: avtoref. dis. ... kand. ekon. nauk [Institutional Synergistic Mechanism for Managing the Transaction Costs of a Vertically Integrated Corporation. Cand. econ. sci. abs. diss.]. Naberezhnye Chelny, INEKA, 2009. 28 p.

Musaev L.A. Otsenka sinergeticheskogo effekta ekonomicheskikh sistem [Evaluation of the Synergistic Effect of Economic Systems]. Vestnik YuRGTU (NPI) [The Bulletin of the SouthRussian State Technical University (NPI)], 2011, no. 3, pp. 132-137.

Nikulina T.A., Romanova I.M., Shmidt Yu.D. Metodika otsenki sinergeticheskogo effekta funktsionirovaniya korporativnykh roznichnykh torgovykh setey [Methodology for Assessing the Synergistic Effect of Corporate Retail Chains]. Ekonomika i predprinimatelstvo [Journal of Economy and Entrepreneurship], 2015, no. 3, pp. 939-945.

Rubtsova N.V. Mezhfirmennye otnosheniya v turizme: rezultaty issledovaniya kompaniy Pribaykalya [Interfirm Relations in Tourism: Results of the Study of the Baikal Companies]. Vestnik SPbGEU. Ser.: Tekhnicheskie nauki, 2014, no. 8 (75), pp. 35-44.

Rubtsova N.V. Effekty setevogo vzaimodeystviya v sfere turistsko-rekreatsionnykh uslug regiona (na primere Sibirskogo federalnogo okruga) [The Effects of Network Interaction in the Area of Tourist-Recreational Services of the Region (On the Example of the Siberian Regions)]. Mir ekonomiki i upravleniya [World of Economics and Management],2018, vol. 18, no. 4, pp. 217-232.DOI: https:/doi.org/10.25205/2542-0429-2018-18-4217-232.

Samarukha V.I. Kontseptsiya razvitiya turizma v Baykalskom regione [The Concept of Tourism Development in the Baikal Region]. Nauch.tekhn. vedomosti SPbGPU [St. Petersburg Polytechnical University Journal: Physics and Mathematics], 2012, no. 3, pp. 184-189.

Sanina L. Opyt okazaniya gosudarstvennoy podderzhki subyektam malogo i srednego predprinimatelstva $\mathrm{v}$ regionakh Rossii [Experience of Giving State Support to Small and Medium Business Entities in Russia's Regions]. Baikal Research Journal, 2014, no. 3.

Svetnik T.V., Bubaeva T.Yu. Strategicheskoe upravlenie sozdaniem osoboy ekonomicheskoy zony turistsko-rekreatsionnogo tipa v Respublike Buryatiya [Strategic Management of Creating a Special Economic Zone for Tourism and Recreation in Buryatia]. Baikal Research Journal, 2011, no. 5.

Chepinoga O.A., Solodkov M.V., Semenova A.E. Problemy funktsionirovaniya i perspektivy razvitiya osobykh ehkonomicheskikh zon v Rossii [Problems of Functioning and Development Prospects for Special Economic Zones in Russia]. Baikal Research Journal, 2017, vol. 8, no. 3. DOI: https://doi.org/10.17150/2411-6262.2017.8(3).4.

Chistyakova O.V. Perspektivy razvitiya turistskorekreatsionnoy osoboy ekonomicheskoy zony «Vorota Baykala»[The Prospects for the Development of Tourist and Recreational Special Economic Zone "Gate of Baikal"]. Izvestiya Irkutskoy gosudarstvennoy ekonomicheskoy akademii (Baykalskiy gosudarstvennyy universitet ekonomiki i prava), 2012, no. 3, pp. 108-112.

Copp C., Ivy R. Networking Trends of Small Tourism Businesses in Post-Socialist Slovakia. Journal of Small Business Management, 2001, no. 39 (4), pp. 345-353.

Dredge D. Policy Networks and the Local Organization of Tourism. Tourism Management, 2006, no. 27 (2), pp. 269-280.

Erkus O.H. The Role of Local and Global Networking for Tourism Rms and Clusters: The Case of Antalya. Unpublished PhD Thesis of Middle East Technical University. Ankara, 2008. 328 p.

Gibson L., Lynch P., Morrison A. The Local Destination Tourism Network: Development Issues. Tourism 
and Hospitality Planning \& Development, 2005, no. 2 (2), pp. 87-99.

Halme M. Learning for Sustainable Development in Tourism Networks. Business Strategy and the Environment, 2001, no. 10 (2), pp. 100-114.

Hilal E.O. The Signicance of Networking and Company Size in the Level of Creativeness of Tourism Companies: Antalya Case. European Planning Studies, 2010, vol. 18, no. 8, pp. 1247-1266.

Keller P. The Future of SMEs in Tourism. St. Gallen, AIEST, 2004, pp. 7-21.
Lemmetyinen A., Go F. The Key Capabilities Required for Managing Tourism Business Networks. Tourism Management, 2008, no. 30 (1), pp. 31-40.

Morrison A., Lynch P., Johns N. International Tourism Network. International Journal of Contemporary Hospitality Management, 2004, no. 16 (3), pp. 197-202.

Scott N., Baggio R., Cooper C. Network Analysis and Tourism: From Theory to Practice (Aspects of Tourism). Clevedon, Channel View Publications, 2008. 258 p.

\section{Information About the Author}

Natalia V. Rubtsova, Candidate of Sciences (Economics), Associate Professor, Department of Management, Marketing and Service, Baikal State University, Lenin St., 11, 664003 Irkutsk, Russian Federation, runatasha21@yandex.ru, https://orcid.org/0000-0002-1400-0509

\section{Информация об авторе}

Наталья Владимировна Рубцова, кандидат экономических наук, доцент кафедры менеджмента, маркетинга и сервиса, Байкальский государственный университет, ул. Ленина, 11, 664003 г. Иркутск, Российская Федерация, runatasha21@yandex.ru, https://orcid.org/0000-0002-1400-0509 